\title{
ANALISIS KEMAMPUAN PEMAHAMAN MATEMATIS PADA MATA KULIAH ALJABAR LINIER ELEMENTER
}

\author{
Angra Meta Ruswana \\ Universitas Galuh, Jl. R. E. Martadinata No. 150 Baregbeg Ciamis 46251 \\ angra.meta@gmail.com
}

\begin{abstract}
This study aims to analyze the achievement of each indicator that measures the ability of students' mathematical understanding on the subjects of elementary linear algebra. This research is a qualitative descriptive research that seeks to describe the the ability of students' mathematical understanding analysis. The subjects of the study were students of level 2 mathematics education with 2 clasess consisting of 33 students. Data collection methods used includethe ability of students' mathematical test in elementary linear algebra which includes material of linear equation system, matrix and determinat. Based on the result of the research, it is concluded that the level of the ability of students' mathematical understanding elementary linear algebra is as follows: There are 6 students who got score below 50, there are 5 students who got score between 51 and 60 , there are 9 students got score between 61 and 70, there are 5 students got score between 71 and 80, there are 6 students got score between 81 and 90 and there are 2 students got score 91 and up.
\end{abstract}

Keywords: The Ability of Students' Mathematical Understanding, Elementary Linear Algebra.

\begin{abstract}
Abstrak
Penelitian ini bertujuan untuk menganalisis ketercapaian setiap indikator yang mengukur kemampuan pemahaman matematis mahasiswa pada mata kuliah Aljabar Linier Elementer. Penelitian ini adalah penelitian deskriptif kualititatif yang berupaya untuk mendeskripsikan analisis kemampuan pemahaman matematis mahasiswa. Subjek penelitian adalah mahasiswa pendidikan matematika tingkat 2 sebanyak 2 kelas yang berjumlah 33 mahasiswa. Metode pengumpulan data yang digunakan meliputi tes kemampuan pemahaman matematis mahasiswa pada mata kuliah Aljabar Linier Elementer yang meliputi materi sistem persamaan linear, matriks dan determinan. Berdasarkan hasil penelitian disimpulkan bahwa tingkat kemampuan mahasiswa matematika pada mata kuliah Aljabar Linier Elementer adalah sebagai berikut: Terdapat 6 mahasiswa yang mendapat nilai di bawah 50, terdapat 5 mahasiswa yang mendapat nilai antara 51 dan 60 , terdapat 9 mahasiswa yang mendapat nilai antara 61 dan 70, terdapat 5 mahasiswa yang mendapat nilai antara 71 dan 80, terdapat 6 mahasiswa yang mendapat nilai antara 81 dan 90 dan terdapat 2 mahasiswa yang mendapat nilai 91 ke atas.
\end{abstract}

Kata kunci: Kemampuan Pemahaman Matematis, Aljabar Linier Elementer

Pendidikan berperan penting dalam perkembangan kualitas sumber daya manusia termasuk di dalamnya mahasiswa Program Studi Pendidikan Matematika FKIP Universitas Galuh. Pengembangan kualitas SDM bertujuan untuk meningkatkan kemampuan matematis mahasiswa. Pengembangan ini tidak hanya berguna untuk memperoleh hasil belajar matematika yang tinggi, lebih dari itu sebagai bekal bagi mahasiswa untuk menjalani kehidupan bermasyarakat. Seperti yang ditulis Turmudi (2008) bahwa mengetahui matematika mungkin menjadi kepuasan personal, bahkan suatu digdaya, yang menopang kehidupan sehari-hari secara meningkat umumnya bersifat matematika dan teknologi.

Mahasiswa Program Studi Pendidikan Matematika Universitas Galuh berasal dari berbagai macam latar belakang pendidikan, hal ini menjadi salah satu faktor penyebab beberapa mahasiswa merasa kesulitan dalam mengikuti proses pembelajaran dalam mata kuliah Aljabar Linier Elementer. Dampak dari mahasiswa yang mengalami masalah atau kesulitan belajar pada jenjang sekolah dasar sampai sekolah menengah adalah pada kemampuan pemahaman matematisnya ketika berada pada 
bangku perkuliahan.

Mata kuliah Aljabar Linier Elementer dalam struktur kurikulum Jurusan S1 Pendidikan Matematika FKIP Universitas Galuh diberikan pada mahasiswa semester 3. Mata kuliah ini membahas tentang materi sistem persamaan linear dan matriks, determinan, vektor pada ruang dimensi 2 dan ruang dimensi 3, ruang vektor euclidean runag vektor umum. Beberapa materi pada perkuliahan ini sebenarnya sudah diberikan pada jenjang sebelumnya, sehingga diharapkan nilai ujian mahasiswa baik itu ujian tengah semester maupun ujian akhir semester mendapatkan hasil yang memuaskan tetapi nilai yang dihasilkan belum cukup memuaskan. Hal ini menunjukkan bahwa mahasiswa kurang menguasai konsep-konsep matematika pada jenjang sebelumnya karena kebanyakan dari mereka hanya sekedar menghafal konsepnya bukan memahaminya.

Pemahaman matematis merupakan salah satu tujuan yang diharapkan bisa tercapai dengan baik oleh siswa. Istilah pemahaman berbeda menurut siapa yang memahami sesuatu, apa yang dipahami dan cara atau bagaimana ia memahami hal tersebut (Ansari, 2003). Pemahaman merupakan terjemahan dari understanding yang artinya adalah menyerap arti dari suatu materi yang sedang dipelajari. . Pemahaman matematis sebagai suatu tujuan, berarti suatu kemampuan memahami konsep, membedakan sejumlah konsep-konsep yang saling terpisah, serta kemampuan melakukan perhitungan secara bermakna pada situasi atau permasalahan yang lebih luas (Syarifah, 2017).

Kemampuan pemahaman adalah salah satu tujuan yang harus dikuasai siswa. Delvin (Oktavien, 2012) menyatakan bahwa pemahaman merupakan unsur penting dalam setiap pembelajaran di semua jenjang pendidikan, baik jenjang pendidikan persekolahan maupun perguruan tinggi. Pemahaman berkaitan dengan penguasaan atau mengerti tentang sesuatu. Kemampuan pemahaman merupakan kemampuan paling mendasar yang harus dimiliki mahasiswa karena kemampuan ini bisa menunjang mahasiswa untuk mencapai kemampuan berpikir matematis lainnya. Sumarmo (2003) menyatakan bahwa pemahaman matematis penting dimiliki mahasiswa karena diperlukan untuk menyelesaikan masalah matematika, masalah dalam disiplin ilmu lain, dan masalah dalam kehidupan sehari-hari, yang merupakan visi pengembangan pembelajaran matematika untuk memenuhi kehidupan masa kini.

Anderson et al. (Kesumawati, 2011), menyatakan understand is defined as constructing the meaning of instructional messages, including oral, written, and graphic communication. Menurut pendapat tersebut, siswa dikatakan memahami sesuatu jika mereka mampu mengkonstruksi makna dari pesan-pesan pengajaran seperti komunikasi lisan, tulisan, dan grafik. Tingkat pemahaman seseorang terhadap suatu konsep dapat dilihat dari jenis-jenis pemahaman yang dimilikinya.

Skemp (Sumarmo, 2010) menyatakan bahwa terdapat dua jenis kemampuan pemahaman, yaitu: 1) Pemahaman instrumental yang artinya hapal sesuatu secara terpisah atau dapat menerapkan sesuatu pada perhitungan rutin/sederhana, mengerjakan sesuatu secara algoritmik. Pada pemahaman ini siswa hanya menghapal rumus dan urutan pengerjaan dan algoritma saja; 2) Pemahaman relasional 
yang berarti dapat melakukan perhitungan secara bermakna pada permasalahan-permasalahan yang lebih luas, termuat skema atau struktur yang dapat digunakan pada penyelesaian yang memuat masalah yang lebih luas, dapat mengaitkan suatu konsep/prinsip lainnya dan sifat pemakaiannya lebih bermakna.

Polya (Sumarmo, 2010), menyatakan empat tingkat pemahaman matematis suatu hukum, yaitu pemahaman mekanikal, pemahaman induktif, pemahaman rasional dan pemahaman intuitif. Pemahaman mekanikal berarti dapat mengingat dan menerapkan hukum secara benar. Pemahaman induktif berarti menerapkan hukum ke dalam kasus sederhana dan meyakini bahwa hukum bisa diberlakukan untuk kasus yang serupa. Pemahaman rasional berarti dapat membuktikan kebenaran dari suatu hukum. Pemahaman intuitif berarti meyakini hukum tanpa keragu-raguan dan memberikan prediksi dengan bukti kebenarannya. Polattsek (Sumarmo, 2010), membedakan dua jenis pemahaman, yaitu: (1) Pemahaman komputasional, yaitu dapat menerapkan sesuatu pada perhitungan rutin/sederhana, atau mengerjakan sesuatu secara algoritmik saja; (2) Pemahaman fungsional, yaitu dapat mengkaitkan sesuatu dengan hal lainnya secara benar dan menyadari proses yang dilakukan.

Copeland (Sumarmo, 2010), kemampuan pemahaman ada dua jenis, yaitu: (1) Knowing how to, yaitu mengerjakan sesuatu secara rutin/algoritmik; (2) Knowing, yaitu dapat mengerjakan sesuatu dengan sadar akan proses yang dikerjakannya. Secara umum, indikator pemahaman matematika meliputi: mengenal, memahami, dan menerapkan konsep, prosedur, prinsip, dan ide matematika. (Sumarmo, 2010:4). Pada penelitian ini indikator pemahaman matematis yang digunakan adalah indikator pemahaman menurut Jihad dan Haris (2010:149) adalah sebagai berikut:
a. Kemampuan mengklasifikasikan objek-objek menurut sifat-sifat tertentu.
b. Kemampuan menggunakan, memanfaatkan, dan memilih prosedur atau operasi tertentu.
c. Kemampuan mengaplikasikan konsep atau algoritma pemecahan masalah.

\section{METODE PENELITIAN}

Metode yang digunakan dalam penelitian ini adalah metode penelitian deskriptif kualitatif. Sukardi (2008:157) menyatakan bahwa peneitian deskriptif merupakan penelitian yang menggambarkan aturan atau menginterpretasikan objek sesauai dengan apa adanya, dimana peneliti ingin mengungkapkan kemampuan pemahaman mahasiswa dalam mata kuliah Aljabar Linier Elementer. Penelitian kualitaif merupakan penelitian yang digunakan untuk menyelidiki, menemukan, menggambarkan, dan menjelaskan kualitas atau keistimewaan dari pengaruh social yang tidak dapat dijelaskan, diukur atau digambarkan melalui pendekatan kuantitaif (Saryono, 2010: 1). Penelitian kualitatif digunakan untuk mendapatkan analisis data yang mendalam dan bermakna. Dengan maksud mendeskripsikan fenomena, dimana peneliti mengungkapkan pemahaman matematis mahasiswa dalam mata kuliah Aljabar Linier Elementer dengan materi sisterm persamaan linier dan determinan. 
Penelitian dilakukan di Universitas Galuh tahun akademik 2018/2019 semester ganjil. Subyek penelitian adalah pada mahasiswa Program Studi Pendidikan Matematika sebanyak 2 kelas yang berjumlah 33 mahasiswa. Metode pengumpulan data yang digunakan meliputi: (1) tes kemampuan pemahaman matematis; (2) observasi; (3) wawancara; dan (4) dokumentasi. Penelitian dilaksanakan pada bulan September 2018 sampai November 2018.

Tes yang digunakan dalam penelitian ini adalah tes soal pemahaman matematis yang terdiri atas 5 soal essay. Soal tersebut mencakup indikator pemahaman matematis yaitu: Kemampuan menggunakan, memanfaatkan, dan memilih prosedur atau operasi tertentu, kemampuan mengaplikasikan konsep atau algoritma pemecahan masalah, dan kemampuan mengklasifikasikan objek-objek menurut sifat-sifat tertentu.

Soal nomor pertama untuk mengukur kemampuan mahasiswa dalam mengaplikasikan konsep atau algoritma pemecahan masalah dalam menyelesaikan matriks. Soal nomor kedua untuk mengukur kemampuan mahasiswa dalam mengaplikasikan konsep atau algoritma pemecahan masalah dalam menyelesaikan sistem persamaan linear menggunakan eliminasi Gauss-Jordan. Soal nomor tiga untuk mengukur kemampuan mahasiswa dalam mengklasifikasikan objek-objek menurut sifat-sifat tertentu dalam menyelesaikan invers matriks. Soal nomor empat untuk mengukur kemampuan mahasiswa dalam menggunakan, memanfaatkan, dan memilih prosedur atau operasi tertentu dalam aturan cramer. Soal nomor lima untuk mengukur kemampuan mahasiswa menggunakan, memanfaatkan, dan memilih prosedur atau operasi tertentu dalam menyelesaikan determinan menggunakan reduksi baris.

\section{HASIL DAN PEMBAHASAN}

Setelah menganalisa data yang diperoleh, maka didapat skor kemampuan pemahaman sebagai berikut : Terdapat 6 mahasiswa yang mendapat nilai di bawah 50, terdapat 5 mahasiswa yang mendapat nilai antara 51 dan 60, terdapat 9 mahasiswa yang mendapat nilai antara 61 dan 70, terdapat 5 mahasiswa yang mendapat nilai antara 71 dan 80, terdapat 6 mahasiswa yang mendapat nilai antara 81 dan 90 dan terdapat 2 mahasiswa yang mendapat nilai 91 ke atas. Nilai pemahaman matematis pada setiap indikator, dapat dilihat pada Tabel 1 berikut :

\section{Tabel 1.}

Ketercapain Kemampuan Pemahaman Matematis untuk Setiap Soal

\begin{tabular}{|c|c|c|c|c|}
\hline $\begin{array}{l}\text { No. } \\
\text { Soal }\end{array}$ & Indikator Kemampuan yang Diukur & $\begin{array}{l}\text { Rata- } \\
\text { Rata } \\
\text { Skor }\end{array}$ & $\begin{array}{c}\text { Skor } \\
\text { Maksimum }\end{array}$ & $\begin{array}{c}\text { Ketercapaian } \\
(\%)\end{array}$ \\
\hline 1. & $\begin{array}{l}\text { Mahasiswa mampu mengaplikasikan konsep atau } \\
\text { algoritma pemecahan masalah dalam menyelesaikan } \\
\text { matriks }\end{array}$ & 9 & 10 & 90 \\
\hline 2. & $\begin{array}{l}\text { Mahasiswa mampu mengaplikasikan konsep atau } \\
\text { algoritma pemecahan masalah dalam menyelesaikan } \\
\text { sistem persamaan linear menggunakan eliminasi } \\
\text { Gauss-Jordan }\end{array}$ & 12 & 20 & 58 \\
\hline 3. & Mahasiswa dapat mengklasifikasikan objek-objek & 19 & 30 & 51 \\
\hline
\end{tabular}




\begin{tabular}{lllll}
\hline \multicolumn{6}{l}{$\begin{array}{l}\text { menurut sifat-sifat tertentu dalam menyelesaikan } \\
\text { invers matriks }\end{array}$} & & & \\
\hline 4. & $\begin{array}{l}\text { Mahasiswa dapat dalam menggunakan, } 17 \\
\text { memanfaatkan, dan memilih prosedur atau operasi } \\
\text { tertentu dalam aturan cramer }\end{array}$ & 20 & 67 \\
\hline $5 . \quad \begin{array}{l}\text { Mahasiswa dapat menggunakan, memanfaatkan, dan } \\
\text { memilih prosedur atau operasi tertentu dalam } \\
\text { menyelesaikan determinan menggunakan reduksi } \\
\text { baris }\end{array}$ & & 20 & \\
\hline
\end{tabular}

Berdasarkan hasil analisa pada tabel 1 , terlihat bahwa untuk soal nomor pertama dan soal nomor ke empat, mencapai $90 \%$ dan $83 \%$, ketercapaian mahasiswa sudah baik karena mahasiswa mampu mengaplikasikan konsep atau algoritma pemecahan masalah dalam menyelesaikan matriks dan mahasiswa dapat dalam menggunakan, memanfaatkan, dan memilih prosedur atau operasi tertentu dalam aturan cramer. Untuk soal nomor kedua mencapai 58\%, soal nomor ke tiga $51 \%$ dan soal nomor ke lima 67\%. Hal ini berati secara keseluruhan untuk indikator tersebut rata-rata belum mencapai $70 \%$. Pada soal nomor kedua dengan indikator mengaplikasikan konsep atau algoritma pemecahan masalah dalam menyelesaikan sistem persamaan linear menggunakan eliminasi GaussJordan, beberapa mahasiswa masih kebingungan dalam menetukan operasi baris elementer yang tepat untuk menyelesaikan sistem persamaan linier. Pada soal nomor tiga dengan indikator mengklasifikasikan objek-objek menurut sifat-sifat tertentu dalam menyelesaikan invers matriks, ratarata kesalahan mahasiswa dalam menghasilkan matriks kofaktor yang akan digunakan untuk menentukan adjoin matriks. Sedangkan untuk soal nomor lima, mahasiswa kesulitan dalam menentukan kebalikan dari operasi baris elementer dalam menyelesaikan reduksi baris.

Berdasarkan hasil tersebut, maka dapat disimpulkan bahwa pemahaman matematis mahasiswa masih kurang dari nilai yang ditentukan yaitu 70. Pada materi sistem persamaan linier yaitu menyelesaikan sistem persamaan linear denganmenggunakan eliminasi Gauss-Jordan, umumnya mahasiswa mengalami kebingungan dalam menentukan operasi baris elementer dan beberapa salah dalam mengerjakan perhitungan operasi baris elementer tersebut, seperti yang harusnya bernilai negatif menjadi bernilai positif, yang harusnya dikalikan kemudian ditambah dengan nilai tertentu tetapi nilai penambahnya keliru. Berdasarkan hasil wawancara, pada umumnya mereka paham bagaimana penyelesaian sistem persamaan linear dengan menggunakan eliminasi Gauss-Jordan, namun dari beberapa mahasiswa yang menjawab salah itu karena mereka merasa tidak yakin atau terburu-buru dalam mengerjakan sehingga jawabannya menjadi keliru.

Materi lainnya adalah invers matrik dengan menggunakan adjoin dan determinan dengan ekspansi kofaktor, beberapa jawaban yang tidak tepat adalah dalam menentukan mariks kofaktor yang berasal dari matriks kofaktor karena mahasiswa kebingungan dalam mencari minor dan kofaktor dari matriks. Berdasarkan analisis dari lembar jawaban mahasiswa, kesalahan dalam mencari minor adalah menghilangkan salah satu baris atau kolom. Sedangkan dalam mencari kofaktor adalah dalam 
menentukan hasil akhir yang bernilai positif atau negatif karena awalnya sudah salah dalam menentukan minor. Berdasarkan hasil wawancara dengan mahasiswa, mereka merasa sudah benar dalam menghilangkan pasangan baris dan kolomnya tapi karena tidak teliti mengerjakan, ternyata yang dikerjakan kurang tepat.

Sedangkan untuk materi determinan dengan menggunakan reduksi baris, jawaban mahasiswa yang tidak sesuai adalah dalam mengalikan baris atau kolom dengan suatu skalar. Yang seharusnya nilai skalar tersebut adalah faktor dari angka pada suatu baris ata kolom, tapi ini malah kebalikannya, contohnya dalam suatu baria ada angka 3, maka skalarnya adalah 3, namun dituliskan kebalikannya yaitu 1/3. Selain itu juga, mahasiswa ada yang lupa membubuhkan tanda kebalikan ketika baris atau kolom dipertukarkan. Berdasarkan hasil wawancara, mahasiswa merasa apa yang dikerjakan sesuai dengan operasi baris elementer pada sistem persamaan linear padahal untuk reduksi baris berbeda dan benar mahasiswa ada yang lupa membubuhkan tanda kebalikan ketika menukar baris atau kolom.

Dari beberapa indikator kemampuan pemahaman matematis yang diukur, nilai tertinggi adalah pada indikator nomor satu mengaplikasikan konsep atau algoritma pemecahan masalah dalam menyelesaikan matriks. Sedangkan untuk nilai terendah adalah pada nomor tiga yaitu mengklasifikasikan objek-objek menurut sifat-sifat tertentu dalam menyelesaikan invers matriks.

\section{KESIMPULAN}

Sesuai dengan hasil analisa data, tingkat pemahaman matematis mahasiswa dalam mata kuliah Aljabar Linear Elementer adalah sebagai berikut : Terdapat 6 mahasiswa yang mendapat nilai di bawah 50, terdapat 5 mahasiswa yang mendapat nilai antara 51 dan 60, terdapat 9 mahasiswa yang mendapat nilai antara 61 dan 70, terdapat 5 mahasiswa yang mendapat nilai antara 71 dan 80, terdapat 6 mahasiswa yang mendapat nilai antara 81 dan 90 dan terdapat 2 mahasiswa yang mendapat nilai 91 ke atas. Dari 3 indikator yang diberikan dalam tes kemampuan pemahaman matematis, ada 2 soal yang memenuhi ketercapaian indikator yang diukur sedangkan 3 soal lainnnya belum memenuhi ketercapaian indikator yang diukur.

Berdasarkan kesimpulan tersebut, maka saran yang dapat dikemukakan adalah :

1. Interaksi di kelas antara dosen dan mahasiswa maupun mahasiswa dengan mahasiswa harus lebih ditingkatkan, karena dengan hal itu akan membuat pemahaman mahasiswa lebih berkembang.

2. Pengembangan bahan ajar diperlukan agar kemampuan berpikir mahasiswa menjadi lebih baik dan bisa meningkatkan kemampuan pemahaman matematisnya.

\section{DAFTAR PUSTAKA}

Ansari, B.I. (2003). Menumbuhkembangkan Kemampuan Pemahaman dan Komunikasi Matematik melalui Strategi Think-Talk-Write (Eksperimen di SMUN kelas I Bandung). Disertasi Doktor pada PPS UPI Bandung: tidak Diterbitkan.

Jihad, A. dan Haris. 2010. Evaluasi Pembelajaran. Yogyakarta: Multi Pressindo. 
Kesumawati, N. (2011). Peningkatan Kemampuan Pemahaman, Pemecahan Masalah dan Disposisi Matematis Siswa SMP melalui Pendekatsn Matematika Realistik. Disertasi pada SPs UPI. Bandung : Tidak diterbitkan.

Oktavien, Y. (2012). Meningkatkan Kemampuan Pemahaman dan Pemecahan Masalah Matematis Siswa Sekolah Menengah Atas melalui Pembelajaran Kooperatif Tipe Jigsaw : Studi Eksperimen Di Sma Negeri 1 Rengat. Tesis pada SPs UPI. Bandung: Tidak diterbitkan.

Saryono. 2010. Metodologi Penelitian Kualitatif dalam Bidang Kesehatan. Yogyakarta: Nuha Medika.

Sukardi. 2008. Metodelogi Penelitian Pendidikan. Bumi Aksara : Jakarta.

Sumarmo, U. 2010. Berfikir dan Disposisi Matematik: Apa, Mengapa, dan Bagaimana dikembangkan pada Peserta Didik. Tersedia di http://id.scribd.com/doc/76353753/B erfikir-dan-Disposisi-MatematikUtari [diakses 10-07-2018].

Syarifah, Lely Lailatus. 2017. Analisis Kemampuan Pemahaman Matematis Pada Mata Kuliah Pembelajaran Matematika SMA II. JPPM Vol, 10 No.2.

Turmudi. (2008). Landasan Filsafat dan Teori Pembelajaran Matematika (berparadigma Eksploratif dan Investigasi). Jakarta: Leuser Cita Pustaka. 